government support. Additional donor support is also essential. Fees, too, may need to be increased in those cases where they are low or nonexistent.

Regional graduate centers need to be encouraged. South Africa has become a major regional center for graduate education. Hopefully, the new Pan-African University, established by the African Union, will fill part of that need. It is designed to focus on graduate education in targeted areas, beginning with five regional campuses. Other possibilities for regional centers might be Senegal with its long history of regional activity and Ghana that has greatly improved graduate programs.

A major effort needs to be made to expand faculty $\mathrm{PhD}$ training, because the number of PhDs in sub-Saharan African universities has declined markedly. We applaud the efforts of the Carnegie Corporation in that area and encourage other donors to join in that effort.

\section{The Future}

A key goal for the future is to maintain and expand highquality graduate education. Successes will not come without major new investments in graduate education by those governments that recognize the benefits of high-quality graduate programs, from faculty members who make a commitment to high-quality research and teaching, from students who have the intellectual capacity for intensive study, and from contributions from foreign governments, donors, and international organizations. Such commitments will help revive stalled national development in much of sub-Saharan Africa and create the conditions for a revival of contributions by African graduate education to national development and knowledge production.

\section{Private Twilight: Wither Private Universities in Kenya}

\section{ISHMAeL I. MUnene}

Ishmael I. Munene is associate professor in the Educational Leadership Department, Northern Arizona University, US. E-mail: Ishmael. Munene@nau.edu.

I $\mathrm{n}$ the latest sign all is not well in Kenya's private university sector. The International University of Professional Studies (IUPS) is on the auction block as auctioneers have seized the main campus and other assets over a Ksh. 280 million (US\$3.I million) debt. Strangely, another private university, Mount Kenya University has offered to purchase
IUPS assets as part of its aggressive expansion strategy. These improbable events point to two contradictory dilemmas in Kenya's private university sector: while the sector is on a downward trend, there are pockets of silver linings in the looming dark clouds.

In the I990s, private universities were promoted as the antidote to the comatose university public sector. With decreasing state subventions, the institutions were bursting at the seams: overcrowding, dilapidated facilities, poorly resourced libraries, and a critical shortage of academic staff. Neoliberal policies of privatization and commercialization, it was expected, would simultaneously generate additional revenues to the system, while continuing to meet demand through overall system growth. The I990 and early 2000 represented the golden age of private university growth in Kenya, as numerous private universities were established to provide an alternative avenue for higher education. Two decades later, there has been a reversal of fortunes; private universities are in dire straits, while public universities have registered a robust resurgent.

Kenya's university enrollment reached 324,560 students in 20I4. Around 244,560 (75\%) are enrolled in public institutions while $80,000(25 \%)$ are in private ones. The total number of universities stands at 67 , of which 3I (46\%) are public institutions ( 22 chartered and 9 affiliate university colleges) while $36(54 \%)$ are private (I7 chartered, 6 affiliated university colleges, and 13 with Letters of Interim Authority to operate). The major surge in public universities occurred in 2012, when 22 universities and university colleges (7I\%) were established. Though the number of private universities supersedes the public ones, in absolute enrollment they are a distant second. The conundrum besetting private universities is a trilogy of three interrelated factors namely, the loss of distinct identity, shift in government policy on higher education, and the resurgence of the public university sector.

\section{We Are All the Same: Identity Crisis}

The growth in private universities in the I990s was driven by Christian churches. This first wave of private university growth saw all the major Christian denominations establish private universities, with the denominational nomenclature proudly declaring the religious affiliation of the institutions-Catholics, Methodists, Nazarene, Presbyterians, Pentecostals, Seventh Day Adventists, and other protestant groups. These religious universities have marketed themselves as providing a distinct brand of higher education, one with religious fervor. At 58 percent, Christian universities today make up the bulk of private universities. The only major religious group that has not established a university is the Muslim community. 
In recent years the distinction between religious and public universities has waned. As competition for students between universities has intensified, religious universities have deemphasized the religious fervor of their education. Deep affiliation with religion or denomination is no longer the linchpin of the universities, and it is less the reason to attend them. Religious privateness has faded; there is less reason to attend the universities if religious enrichment was the objective.

\section{New Lease of Life: Govern ment policy}

State policy has contributed in denting private university growth. Government is viewed in terms of how it promotes public sector growth with cascading effect on the private sector. Delayed regulation has been used by the Kenyan government to address quality concerns in public universities. In 20I2, the Kenyan government repealed the individual laws establishing each state university and replaced them with one common statute that would guide the development and operations of all state universities. Furthermore, the state has mandated the accreditation of state universities, just like their private counterparts. Even though large classes and the large number of contingent faculty in branch campuses pose threats to quality, these symbolic acts have demonstrated the government's concern with quality in the public sector and dented criticism of neglect.

Another macrolevel policy has been public system expansion. Alarmed at the low enrollment in private universities in the face of growing demand, the government has moved with haste to expand the public sector through the creation of demand-absorbing public universities, with the accompanying state-subsidized low tuition fees. In 2012 alone, the government established 22 public universities, by upgrading colleges. The establishment of new public universities has occurred simultaneously with expansion of capacity in existing ones, further boosting public sector market share.

The government's actions point to the preponderant role of the state as a funder and influencer of the public sector roles. The state's expansionary policies have been geared toward public system growth, to the detriment of the private sector.

\section{The Rise of the Phoenix: Public Sector Revitaliztion}

Private decline is also tied to public sector revitalization through privatization. Following the privatization of public universities, sectorial distinctions with private ones have become blurred. State policy has promoted the internal revenue generation by public universities; universities have responded by privatizing and commercializing both academic and nonacademic functions to shore up their bottom lines.

Through module II programs, public universities are able to admit privately sponsored students who pay higher tuition than state-sponsored students but lower than what private universities charge. This has proved popular in market-oriented programs-such as engineering, information technology, medical sciences, and pharmacy. Given the prestige historically attached to public universities, module II programs have become the "first second choice" for those unable to attain the coveted state-sponsored option. In two of Kenya's largest public universities, Kenyatta University and the University of Nairobi, privately sponsored students outnumber government-sponsored ones.

\section{The establishment of new public univer- sities has occurred simultaneously with expansion of capacity in existing ones, further boosting public sector market share.}

Further, public universities have engaged in commercial activities in degrees unimaginable in private institutions. They have established industrial parks, formed joint ventures with private corporations, commercialized their residential and catering services, and leased their facilities at market rates. Revenues generated from tuition fees and commercial activities have been utilized in repair and maintenance of existing facilities and construction of new ones.

Privatization and commercialization have seen the resurgence of the public fiefdom. It has become a magnate for those seeking university education at a moderate cost. This model of public university with robust privatization can only coexist with a dwindling private sector. Nearly all private universities are struggling to raise sufficient students for optimal use of their existing facilities.

\section{The Quality Conundum}

With market-share decline, most private universities have suboptimal enrollment, thus threatening their financial well-being and academic quality. Quality instruction is threatened by staff departure, to the better remunerated unionized ranks in public universities and the presence of large numbers of adjunct faculty who also do not engage in reputation enhancing academic work. In addition, their libraries remain small and underresourced. All these quality-related variables have further undermined the private university sector. 